\title{
Fenomén staroby v slovanských literatúrach
}

\author{
Lenka Štangová (Bratislava)
}

Dagmar Gramshammer-Hohl (ed.): Aging In Slavic Literatures. Essays in Literary Gerontology. Transcript Publishing. Aging Studies. vol. XI. 2017. 283 s. ISBN 978-3-8376-3221-7.

Dagmar Gramshammerová-Hohlová pôsobí ako odborná asistentka na Katedre slovanských štúdií na Univerzite v Grazi. V publikácii Aging in Slavic Literatures (2017) predstavuje súbor esejí, ktorého cielom je ponúknut ucelený prehlad o najnovších poznatkoch $\mathrm{z}$ doterajších výskumov v oblasti slovanskej literárnej gerontológie, ktorú chce prezentovał ako novú výskumnú tému. Publikáciu tvorí dvanást esejí, do ktorých prispeli svojimi výskumami a poznatkami literárni odborníci z rôznych európskych univerzít. Sústredili sa predovšetkým na slovanské literatúry - z Bosny, Chorvátska, Slovenska, Slovinska, Srbska, Pol'ska, Ruska a Ukrajiny. Jednotlivé eseje tak prinášajú rôzne pohlady na proces starnutia a starobu v danom spoločenskom, jazykovom a kultúrnom kontexte. Eseje sú v publikácii prezentované v opačnej chronologickej postupnosti. Začínajú súčasnostou a siahajú až do stredoveku. Sú v nich obsiahnuté významné literárne a historické obdobia, vrátane chorvátskej renesancie, pol'ského klasicizmu či ruského modernizmu.

Gramshammerová-Hohlová považuje výber témy za opodstatnený a prínosný, pretože starnutie je vel'mi častým ústredným motívom v slovanských literatúrach, avšak doposial' sa mu aj z dôvodu chýbajúcich prekladov nevenovala vel'ká pozornost'. Vd’aka anglickým prekladom niektorých analyzovaných titulov sa môže akademická komunita, ale aj širšia verejnost̉ dozvediet' o tejto problematike viac. V každej eseji dochádza $\mathrm{k}$ preukázanému prepojeniu medzi vekom a pohlavím. V príspevku od Mariji Geigerovej Zemanovej a Zdenka Zemana, ktorí sa zaoberajú otázkami sexizmu a rodových stereotypov v románe Kosturi okruga Madison (2012) od Vedrani Rudanovej, je toto prepojenie naj- viditel'nejšie. $\mathrm{V}$ detailnom opise tohto feministického románu je načrtnutý problém marginalizácie chorvátskych žien v dôchodkovom veku a ich nepochopenia zo strany vlastných rodín a chorvátskej spoločnosti. Ked’že si už svoju úlohu matky a manželky splnili, žiadne zásadné životné zmeny sa už od nich neočakávajú. Práve v tomto románe však môžeme chápat starobu ako obdobie nových možností. Hlavná hrdinka je sedemdesiatročná vydatá žena, ktorá opúšta rolu pasívnej a submisívnej manželky a matky a zamýšla sa nad rozvodom, novou láskou a predsudkami zo strany spoločnosti.

Dalšie prínosné eseje zaoberajúce sa otázkou prepojenia veku a rodových stereotypov predstavujú Irina Savkinová a Lubica Volanská. Savkinová analyzuje denníky napísané perom troch ruských žien počas obdobia sovietskeho režimu. Autorka okrem odlišného postavenia mužov a žien poukazuje aj na špecifiká sovietskeho režimu, ktorý do istej miery ovplyvnil spôsob, akým ženy mohli prežit svoj život a najmä obdobie starnutia. Okrem pocitov osamelosti, únavy a monotónneho života sa museli prispôsobit aj tlakom režimu a zaužívaných tradícií. Spôsob, akým dokáže politický režim ovplyvnit vnímanie staroby a vstupu do dôchodku, čiastočne opisuje aj L’ubica Volanská. Zameriava sa na porovnanie autobiografí́ bratislavských a viedenských dôchodcov napísaných $\mathrm{v}$ druhej polovici 20. a na začiatku 21. storočia. Volanská považuje tieto autobiografie za istú formu „priznania“, v ktorých sa staršia generácia „spovedá" tej mladšej a opisuje rôzne formy prežívania staroby v dvoch susediacich krajinách, ktoré sú aj napriek svojej geografickej blízkosti poznačené odlišnými politickými systémami a režimami. Rozdielna historicko-spoločenská minulost' 
ovplyvnila aj skúsenosti týchto dvoch skupín ludí so vstupom do dôchodku.

Okrem postavenia žien v spoločnosti a rozdielneho vnímania staroby na územiach slovanského literárneho sveta odkazuje takmer každá esej na fyzické zmeny človeka, resp. zmeny ludského tela s pribúdajúcim vekom. Niektorí autori sa tejto otázke venujú čisto z mužskej perspektívy, iní ju opisujú z pohladu žien. Irina Savkinová napríklad konštatuje, že v socialistickom režime sa nevenovala žiadna pozornost̉ opisu fyzických zmien ženského a mužského tela, pretože sa už nepovažovali za esteticky a sexuálne prítažlivé. Zaujímavý pohlad na zobrazenie mužského tela v slovinskej literatúre poskytuje vo svojej eseji Andreas Leben. Venuje sa analýze mužského pohlavia, strate mužskosti a sexuálnej túžby, ktoré detailne opísala trojica slovinských autorov 20. storočia: Ivan Mrak, Vitomil Zupan a Lojze Kovačič.

Gramshammerová-Hohlová vytvára v publikácii priestor aj na prepojenie staroby s významnými historickými udalostami danej krajiny. Esej od Liany Goletianiovej, v ktorej sa zaoberá ukrajinským románom Stolittja Jakova od Volodymyra Lysa, je príkladom toho, ako rôzne sa môžeme pozerat na retrospektívne rozprávanie človeka a sumarizovanie jeho životných udalostí. Hlavný hrdina Jakiv, ktorý v diele oslavuje sto rokov, nás sprevádza nielen strastami svojho života, ale oboznamuje nás aj s politickým, kultúrnym a literárnym vývojom Ukrajiny v 20. storočí. Okrem už spomínaných tém je v esejach zastúpená aj otázka identity a exilu. Gramshammerová-Hohlová sa napríklad v jednej z esejí zaoberá prepojením staroby a exilovej literatúry v dielach Vladimíra Nabokova, Milana Kunderu a Miljenka Jergovića. Skúma najmä spôsob, akým exil a následný návrat človeka do rodnej zeme spôsobuje tzv. „životnú diskontinuitu“. Exil je podla autorky do istej miery zodpovedný za stratu vlastnej identity, ktorá sa len velmi tažko opätovne buduje. Niektoré literárne postavy však veria, že po návrate $\mathrm{z}$ exilu získajú spät svoju starú identitu. Autorka nachádza prepojenie medzi starobou a návratom z exilu, čo môže do istej miery predstavovat uzatvorenie „kruhu života“. V d’alších esejach sa Nicoletta Cabassiová a Ilaria Remonatová zaoberajú motívom staroby v ruskej literatúre z historickej perspektívy. Natalia Staglová-Škarová ju hladá najmä v renesančnej dalmátskej poézii a Dimitrios Meletis spolu s Andreou Zinkovou ju bližšie opisujú v dielach Tsing od Davida Albahariho a $O$ starosti od Adelaidy Gertsykovej.

Publikácia Dagmar Gramshammerovej-Hohlovej prináša aktuálne poznatky z oblasti fenoménu staroby a jej prítomnosti v slovanskej spoločnosti a literatúre. Poukazuje na to, že vnímanie veku a starnutia je priamo podmienené historickým a kultúrnym pozadím danej krajiny. Vek sa v esejach využíva ako spôsob zobrazenia ludskej identity a spoločenských vzţahov a výber literárnych diel poskytuje alternatívny pohlad a protiváhu k už zaužívaným spoločenským konvenciám.

\section{Mgr. Lenka Štangová}

Ústav filologických štúdií, Katedra románskych jazykov a literatúr

Pedagogická fakulta, Univerzita Komenského v Bratislave

Račianska 59, 81334 Bratislava, Slovensko

stangova@fedu.uniba.sk

This work can be used in accordance with the Creative Commons BY-SA 4.0 International license terms and conditions (https://creativecommons.org/licenses/by-sa/4.0/legalcode). This does not apply to works or elements (such as image or photographs) that are used in the work under a contractual license or exception or limitation to relevant rights. 